\title{
Broad-Spectrum Antiviral Strategies and Nucleoside Analogues
}

\author{
Robert J. Geraghty $^{1}\left(\mathbb{D}\right.$, Matthew T. Aliota ${ }^{2} \mathbb{D}$ and Laurent F. Bonnac ${ }^{1, *}$ \\ 1 Center for Drug Design, College of Pharmacy, University of Minnesota, Minneapolis, MN 55455, USA; \\ gerag012@umn.edu \\ 2 Department of Veterinary and Biomedical Sciences, University of Minnesota, St. Paul, MN 55108, USA; \\ mtaliota@umn.edu \\ * Correspondence: bonna008@umn.edu
}

\section{check for}

updates

Citation: Geraghty, R.J.; Aliota, M.T.; Bonnac, L.F. Broad-Spectrum Antiviral Strategies and Nucleoside Analogues. Viruses 2021, 13, 667. https://doi.org/10.3390/v13040667

Academic Editor: Cheng-Wen Lin

Received: 18 March 2021

Accepted: 12 April 2021

Published: 13 April 2021

Publisher's Note: MDPI stays neutral with regard to jurisdictional claims in published maps and institutional affiliations.

Copyright: (c) 2021 by the authors. Licensee MDPI, Basel, Switzerland. This article is an open access article distributed under the terms and conditions of the Creative Commons Attribution (CC BY) license (https:// creativecommons.org/licenses/by/ $4.0 /)$.

\begin{abstract}
The emergence or re-emergence of viruses with epidemic and/or pandemic potential, such as Ebola, Zika, Middle East Respiratory Syndrome (MERS-CoV), Severe Acute Respiratory Syndrome Coronavirus 1 and 2 (SARS and SARS-CoV-2) viruses, or new strains of influenza represents significant human health threats due to the absence of available treatments. Vaccines represent a key answer to control these viruses. However, in the case of a public health emergency, vaccine development, safety, and partial efficacy concerns may hinder their prompt deployment. Thus, developing broad-spectrum antiviral molecules for a fast response is essential to face an outbreak crisis as well as for bioweapon countermeasures. So far, broad-spectrum antivirals include two main categories: the family of drugs targeting the host-cell machinery essential for virus infection and replication, and the family of drugs directly targeting viruses. Among the molecules directly targeting viruses, nucleoside analogues form an essential class of broad-spectrum antiviral drugs. In this review, we will discuss the interest for broad-spectrum antiviral strategies and their limitations, with an emphasis on virus-targeted, broad-spectrum, antiviral nucleoside analogues and their mechanisms of action.
\end{abstract}

Keywords: broad-spectrum antivirals; lethal mutagenesis; chain terminator; nucleoside analogues

\section{The Interest of Broad-Spectrum Antiviral Strategies}

Antiviral drug development has long focused on virus-specific approaches: the strategy to study a virus and identify a specific viral protein as a drug target in order to limit potential toxicity and to increase drug efficacy (Figure 1). Virus-specific drug development has also been favored as a way to simplify the drug discovery process compared to the more complex design of broad-spectrum antivirals, which often require targeting critical proteins belonging to different viruses or critical cellular processes used by different viruses. Virus-specific antiviral research remains a successful and essential strategy to combat viral infections [1]. However, a major obstacle to virus-specific drug development is the length of the process, which, on average, takes more than a decade between research and drug approval [2]. Indeed, virus-specific drug development needs first to address fundamental biology of the virus to find an appropriate target before moving to medicinal chemistry research, compounds screening, lead optimization, animal studies and eventual clinical trials. The time constraint for antiviral drug discovery has gradually become more important due to the increasing number of viral outbreaks that have recently and consecutively afflicted our societies including Ebola virus [3], Middle East Respiratory Syndrome coronavirus MERS-CoV [4], Severe Acute Respiratory Syndrome Coronavirus 1 and 2 (SARS and SARS-CoV-2) [5,6], new strains of influenza A virus [7] as well as dengue virus [8], Zika virus [9,10], West Nile virus [11] and Chikungunya virus [12]. Reasons for the increased appearances of these outbreaks include increased population densities, forest fragmentation, intercontinental traveling, and climate change $[13,14]$. Regardless of their origins, the recent and consecutive nature of these outbreaks highlight the challenges of virus-specific 
drug research for fast discovery of a therapeutic. Similarly, vaccine development, although particularly relevant to face outbreaks and pandemics, also requires a significant development time to ensure the efficacy and safety of the vaccine [15]. Re-purposing antiviral drugs, the strategy to evaluate approved drugs for known viruses against new viruses is highly advantageous in terms of reducing cost and saving time, and has therefore been an essential component of emergency responses during public health crisis [16].

\section{Virus replication cycle}

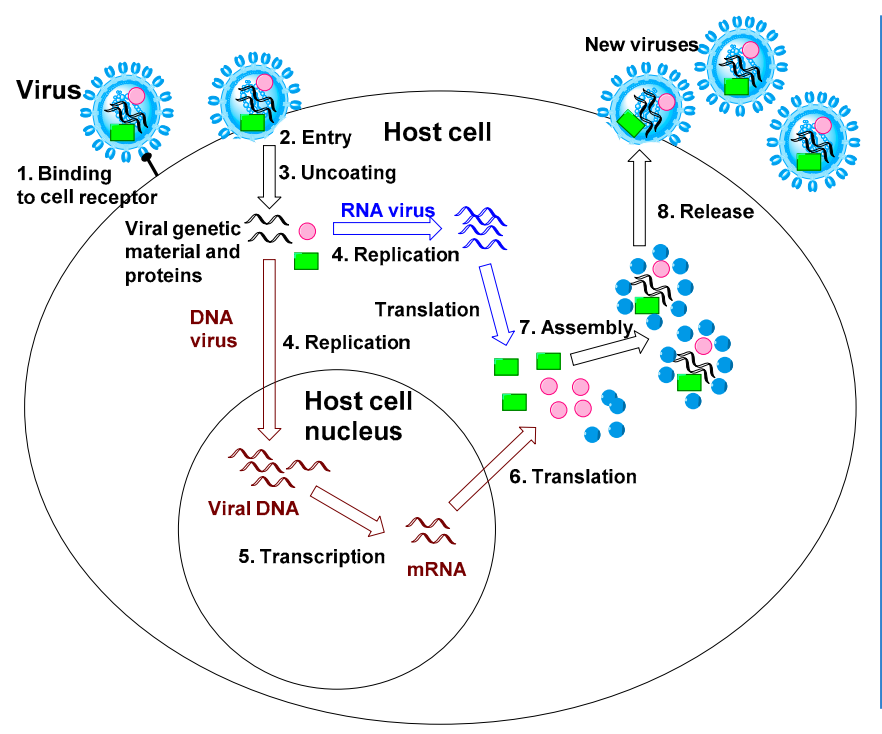

Antiviral strategies

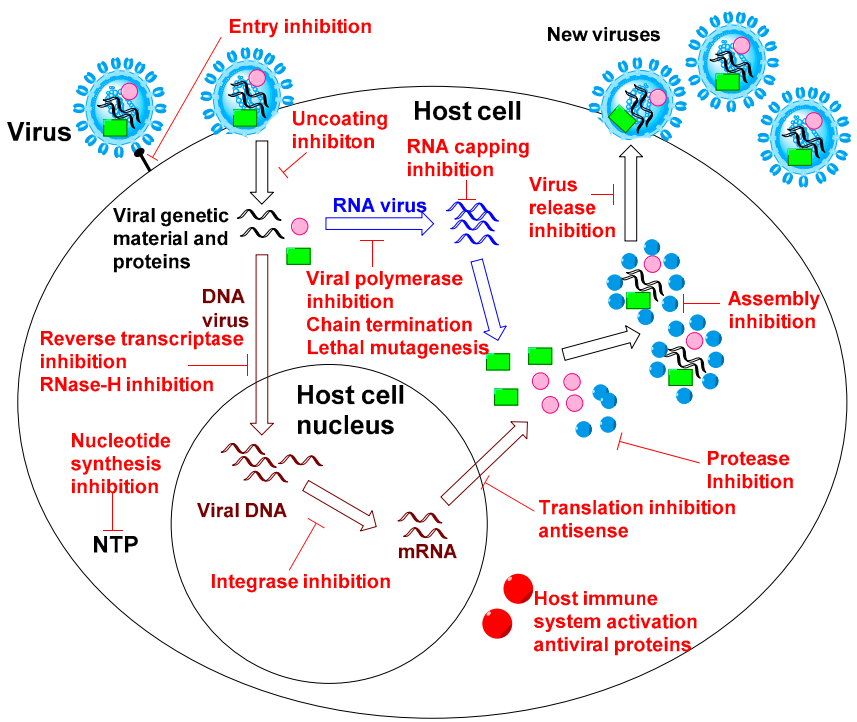

Figure 1. Virus replication cycle and antiviral strategies.

Drug re-purposing is advantageous in that the initial part of the drug discovery process can be bypassed including medicinal chemistry research and lead optimization as well as the safety evaluation in phase 1 clinical trials, therefore reducing considerably the research and development time. Yet, re-purposing antiviral drugs successfully is inherently dependent on the ability of an antiviral drug to be active against multiple viruses, hence, the need of a broad-spectrum antiviral effect. Historically, broad-spectrum antivirals have first been discovered by serendipity through simple screening assays against different viruses rather than through a deliberate strategy to design drugs to display a broadspectrum antiviral effect $[17,18]$ for ribavirin or more recently with antibiotic derivatives with antiviral properties $[19,20]$. From these initial antiviral drug evaluations emerged patterns of drugs with similar biological effects. Broad-spectrum antiviral drugs can be classified into two main categories; first, drugs that affect the host-cell machinery essential for the infection and replication of different viruses, and second; drugs targeting viruses directly. Both families of broad-spectrum antiviral drugs (e.g., host-targeted or virustargeted broad-spectrum antivirals) present advantages, and disadvantages (Table 1).

Table 1. Pros and cons of different antiviral strategies, virus-specific antiviral strategies, host-targeted and virus-targeted broad-spectrum antiviral strategies.

\begin{tabular}{lll}
\hline \multirow{2}{*}{ Virus-Specific Antiviral Strategies } & \multicolumn{1}{c}{ Broad-Spectrum Antiviral Strategies } \\
\cline { 2 - 3 } & \multicolumn{1}{c}{ Host-Targeted } & \multicolumn{1}{c}{ Virus-Targeted } \\
\hline Pros: & Pros: & Pros: \\
- Proven efficacy & - Host proteins broadly required by viruses & - Less potential for toxicity compared to \\
- Easier design, one viral target & - Demonstrated antiviral effect & host-targeted strategies. \\
- Relative safety compared to other strategies & - Higher barrier to drug resistance development & - Potential for repurposing \\
Cons: & Cons: & Cons: \\
- Narrow application & - Not selective & - More complex design \\
- Low barrier to drug resistance development & - Potential for toxicity & - Limited examples of broad-spectrum \\
- Long development time & & antiviral drugs \\
\hline
\end{tabular}




\section{Host-Targeted Antiviral Strategies}

Host-targeted antiviral strategies, reviewed here [21,22], feature a wide range of host targets including host protease inhibition to restrict viral entry, depletion of intracellular nucleotide pools, kinase inhibition, glycosidase inhibition, immune system activation and more. While the main disadvantage of host-targeted antivirals is the higher risk for host toxicity, an advantage is that the host-targets/proteins involved in virus replication are often known and can be studied before a new virus emerges.

A host-targeted approach often offers a higher barrier to the appearance of viral drug resistance. In practice, developing both host-targeted and virus-targeted broad-spectrum antivirals is crucial and complementary to answer the viral outbreaks to come. Virustargeted-broad-spectrum antiviral strategies present their own challenges; the diversity of viral protein structures and sequences make the design of broadly acting compounds particularly difficult, and often result in a limited spectrum of antiviral applications. Up until now, only one class of compounds, nucleoside analogues, has shown promise for broad-spectrum antiviral applications in the clinic. Viruses adopt different replication strategies, yet all replicate their genetic material via a DNA or RNA polymerase conferring potential susceptibility to molecules resembling the natural nucleoside building blocks of their genomes; the antiviral nucleoside analogues. Many viruses also share the ability to adapt rapidly to new stress conditions which makes them vulnerable to antiviral strategies targeting their mutation frequency.

\section{Broad-Spectrum Antiviral Nucleoside Analogues}

Antiviral nucleoside research began in the 1960-1970s [18,23] but demonstrated its enormous potential in the 1980-1990s with the discovery of several anti-HIV drugs such as Abacavir, AZT and other drugs reviewed here $[24,25]$ and since then has expanded its applications to other viral pathogens (Figure 2) [26-28]. Many direct-acting antiviral nucleoside analogues target the viral polymerase responsible for the viral genome replication [29]. Unlike non-nucleoside polymerase inhibitors that often bind to allosteric non-conserved and -mutation-tolerant sites, nucleoside analogues directly bind to the more conserved active site of the viral polymerase after conversion to their triphosphate active form [30].

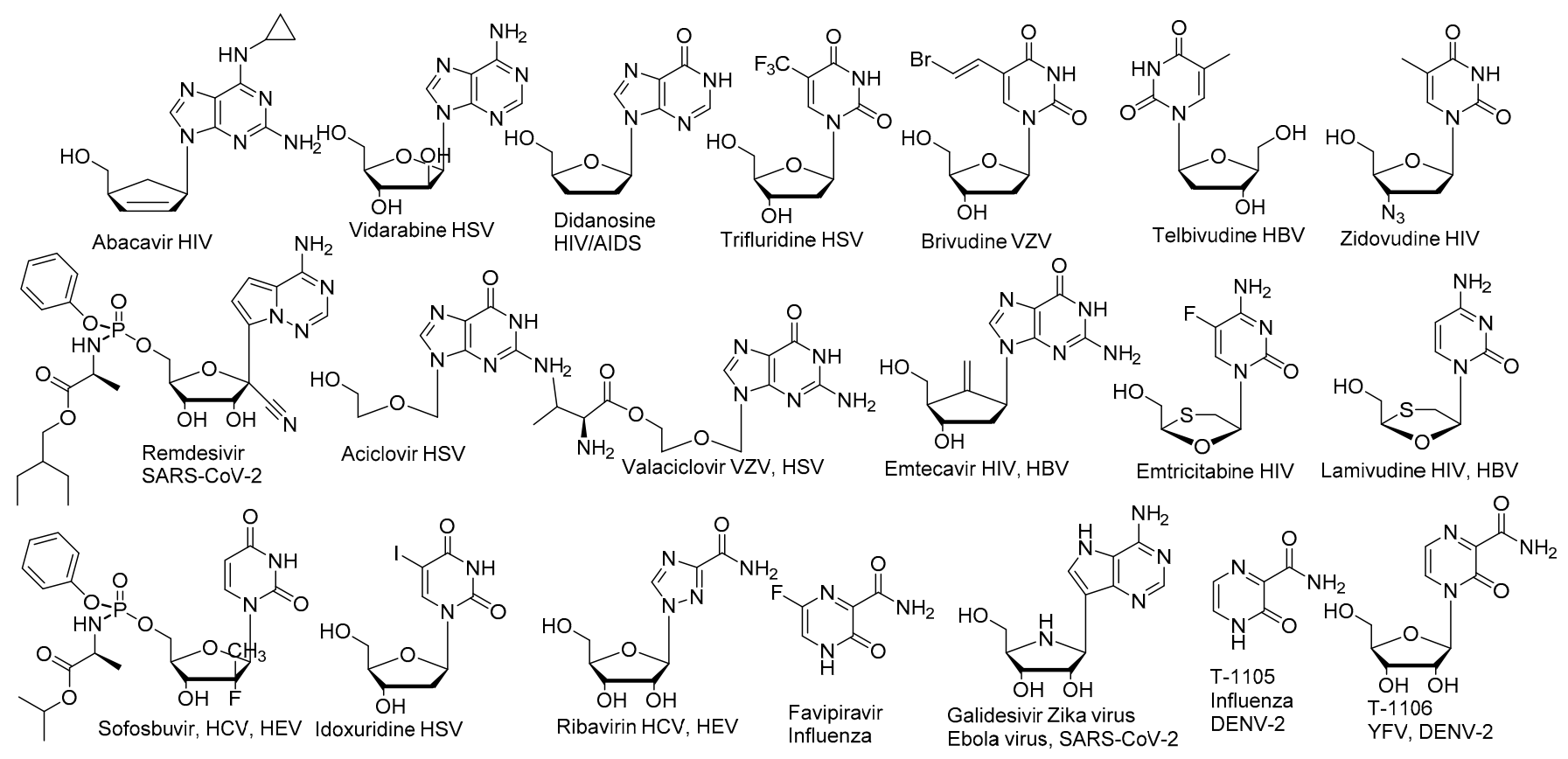

Figure 2. Non-exhaustive list of nucleoside antiviral drugs and other antiviral nucleoside analogues. 
Although antiviral nucleoside analogues form a major class of antiviral drugs (Figure 2), the development of nucleoside antiviral inhibitors faces several challenges. Nucleoside analogue half-life and pharmacokinetics differ significantly from natural nucleoside properties [30]. Many of these challenges originate from the very nature of nucleoside inhibitors that intrinsically require activation by host kinases to their triphosphate active form before becoming substrate of the viral polymerase [31]. The efficiency of antiviral nucleoside triphosphate formation varies significantly from one cell type to another due to the different levels of kinases required for the phosphorylation process, the antiviral nucleoside triphosphate level in cells being recognized as a good indicator for the antiviral activity [1,32]. While the second phosphorylation can be a critical step [33,34], the first phosphorylation is often the rate-limiting step for triphosphate formation for most nucleoside analogues $[30,35]$. Therefore, nucleoside monophosphate prodrugs have been developed successfully to bypass the first phosphorylation issue and result in improved antiviral efficacies [36-38]. This is exemplified by the successful development of the anti$\mathrm{HCV}$ drug Sofosbuvir, a nucleoside phosphoramidate prodrug [1,32] following initially underwhelming studies of poorly active nucleoside analogues [32,39]. The nucleoside phosphoramidate prodrug is able to enter infected cells where it is directly converted to the monophosphate therefore bypassing the first phosphorylation issue.

The definition of "broad-spectrum antiviral" can be considered a matter of scale, with some defining the term to encompass all viruses, or perhaps all RNA viruses, or some defining more narrowly to include all viruses of a particular family. The number of direct-acting and virus-targeted nucleoside analogues displaying an antiviral effect across different virus families is limited. Three nucleoside analogues stand out as broad-spectrum RNA virus inhibitors: Remdesivir, Ribavirin and T-705/Favipiravir. We will further discuss these three nucleoside analogues, their antiviral activities, and mechanisms of action.

\subsection{Remdesivir}

Remdesivir is a $C$-nucleoside analogue and a phosphoramidate prodrug that resembles adenosine monophosphate. The $C$-nucleoside nature of Remdesivir, with the replacement of the natural carbon-nitrogen bond between the base and the sugar, by a carbon-carbon bond, is advantageous in terms of chemical and enzymatic stability (Figure 3). The $C$ nucleoside structure also allows the unusual $1^{\prime}$ modification of the sugar. Nucleosides with a $1^{\prime}$ modifications are often poorly stable with the regular carbon-nitrogen bond between base and sugar and/or difficult to synthesize. The Ebola virus outbreak in West Africa in 2013 increased antiviral drug research and screening resulting in a selection of promising leads. Research centers started intensive studies, including in non-human primates, that lead to the identification of Remdesivir, a broad-spectrum antiviral active against Ebola and, Marburg viruses as well as against MERS-CoV and SARS-CoV-2 [40,41]. Remdesivir is an FDA-approved drug for the treatment of COVID-19 patients [42,43]. Remdesivir displays a remarkably broad antiviral effect [44,45] rare for molecules with similar mode of action through viral RNA chain termination. Before acting as a delayed chain terminator [46,47], the Remdesivir phosphate prodrug must enter infected cells where it is converted metabolically by different enzymes to its triphosphate active form (Figure 3).

Remdesivir, under its triphosphate active form then becomes substrate of the viral polymerase, a highly conserved and critical protein of the viral replication cycle [48,49]. Remdesivir triphosphate mimics the natural substrate nucleotide adenosine triphosphate. Delayed chain termination occurs 3-to-5 nucleotides after Remdesivir triphosphate is incorporated into a growing new strand of viral RNA genome [46,47] leading to a stalling mechanism $[46,48,50]$. It is worth noting that the delayed chain termination might protect Remdesivir from excision by viral proofreading proteins thanks to the 3-5 additional natural nucleotides [51]. The delayed chain termination triggered by Remdesivir forces the premature ending of the viral RNA synthesis. A downside of Remdesivir is the need to administer it intravenously $[43,52]$, likely due to its poor oral bioavailability and short 
half-life [53]. Alternatives to Remdesivir or orally available formulations of Remdesivir are therefore needed to make treatment more practical.

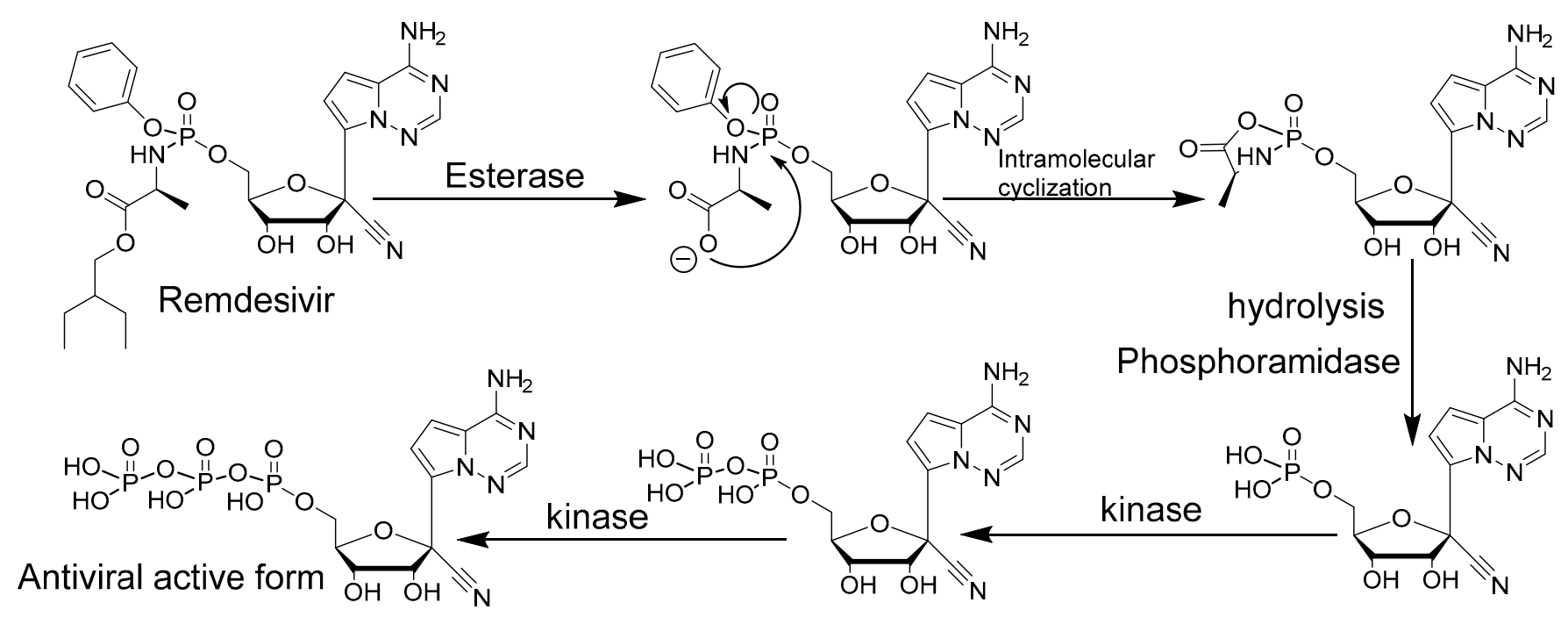

Figure 3. Remdesivir activation mechanism.

\subsection{Ribavirin}

Ribavirin discovered in the 1970s is one of the most remarkable nucleoside antivirals due to its antiviral activities, both in tissue culture and animal models against a uniquely broad range of viruses including DNA and RNA viruses [17] (Figure 4). Ribavirin [18] is an approved drug against hepatitis $C$ infection in combination with interferons alpha or in combination with other medications such as sofosbuvir [54,55]. Ribavirin has also been used for the treatment of other viral infections [56,57]. Structurally, ribavirin possesses a regular ribose moiety linked to a triazole aromatic ring as a base with a rotatable amido group attached to it. The rotatable amido group makes ribavirin resemble adenosine or guanosine upon its rotation. In cells, ribavirin nucleoside is phosphorylated by adenosine kinase to its monophosphate form and further processed by other kinases to its triphosphate form (Figure 4) [58]. The antiviral mechanism of action of Ribavirin is still under investigation and likely comprises multiple mechanisms [59]. These mechanisms include host-targeted effects such as the inhibition of inosine monophosphate dehydrogenase (IMPDH) under its $5^{\prime}$-monophosphate form and host immune response modulation, as well as virus-targeted effects such as viral polymerase inhibition, viral lethal mutagenesis, and viral RNA capping inhibition. The wide variety of viruses susceptible to ribavirin is likely due to the combined antiviral effects triggered by ribavirin [17]. For host-targeted antiviral effects, ribavirin monophosphate inhibits IMPDH [60] which is responsible for the conversion of inosine monophosphate (IMP) to xanthosine monophosphate (XMP). IMPDH role is crucial for DNA and RNA synthesis since IMPDH controls the intracellular guanine nucleotide (GTP and dGTP) pool concentrations which may explain the activity of ribavirin against both DNA and RNA viruses [17]. Ribavirin also possesses an immunomodulatory effect by modifying the host T-cell response through a switch in T-cell phenotypes [61]. Regarding virus targeted antiviral effects, ribavirin, as a guanosine analogue [62], can interact with the RNA capping enzymes [63]. Capped RNAs contains a 7-methylguanosine cap structure essential for RNA stability and translation. Inhibition of viral RNA capping is interesting in that the lack of viral RNA capping triggers the antiviral host immune response by recognition of a foreign viral RNA. Ribavirin also displays virus-targeted effects, with the inhibition of the viral RNA-dependent RNA polymerase (RdRp) and viral lethal mutagenesis. Ribavirin structure is quite different from typical RdRp chain terminators that usually display modifications on the sugar that prevent further elongation of the growing viral RNA. Ribavirin does not have modifications on its sugar moiety but only on its base, so it 
remains unclear how ribavirin inhibits RdRp. Yet ribavirin incorporation can significantly reduce RdRp catalytic efficiency of viral RNA synthesis. It has been demonstrated that ribavirin triphosphate inhibits the influenza A virus RNA polymerase in vitro [64] as well as hepatitis C virus RNA polymerase [65], vesicular stomatitis virus [66,67]. Finally, ribavirin also induces an antiviral effect via viral lethal mutagenesis against several viruses $[68,69]$ including in vivo against hepatitis C [70]. Most RNA viruses possess a high mutation rate that allows them to adapt, escape host immune defenses and drug treatments [71,72]. The high error-prone nature of viral RdRps is widely recognized as the main source for the virus high mutation rate [73,74]. However, RNA viruses possess an error threshold above which genetic information cannot be maintained. Alteration of the viral mutation rate with ambiguous base-pairing nucleoside analogues has been proposed as a potential therapeutic approach, called lethal mutagenesis, targeting high-mutation-rate RNA viruses [75]. Ribavirin increases the viral RNA mutation frequency to non-viable levels thanks to its ambiguous base-pairing capacity. When incorporated into the viral RNA, ribavirin base-pairs equally with uridine or cytosine nucleotides consequently inducing viral mutations $[68,69]$. With the accumulation of deleterious mutations within its genome, the virus no longer maintains the genetic information required for survival, a process called lethal mutagenesis or error-catastrophe. The understudied family of compounds able to induce viral lethal mutagenesis offer a unique chance for broad-spectrum antiviral activity, theoretically able to affect most high-mutation-rate RNA viruses. Overall, ribavirin's ability to mimic both adenosine and guanosine is advantageous in that it allows ribavirin to interact with a variety of enzymes and biological mechanisms critical for the replication cycle of many viruses. The downside of ribavirin resembling adenosine and guanosine is that it enhances the interaction of ribavirin with the host cell machinery resulting in poor selectivity and toxicity [76] yielding undesirable side effects such as severe anemia. Discovery of molecules with similar ambiguous base-pairing capacity but more selective for viral proteins is therefore desirable [77].

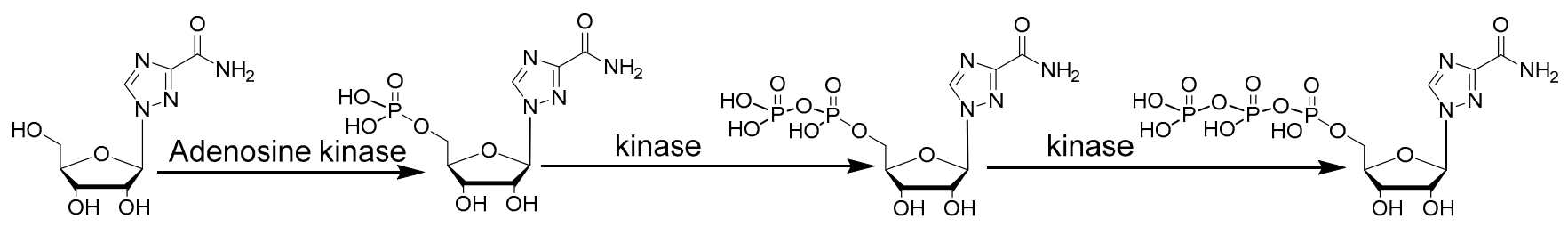

Ribavirin

ribavirin monophosphate IMPDH inhibitor

Antiviral active form

Figure 4. Ribavirin activation mechanism.

\subsection{T-705 Favipiravir}

As mentioned in Section 3.2., compounds able to induce viral lethal mutagenesis offer a unique opportunity for broad-spectrum antiviral activities. Viral lethal mutagenesis is interesting because even a small increase in the viral mutation rate can have a devastating negative impact on virus replication. The lethal mutagenesis inducer ribavirin is broadly active yet poorly selective and toxic, thus alternatives are needed. An approved drug in Japan against influenza T-705 (Favipiravir/Avigan) (Figure 5) possesses a broad-spectrum antiviral effect $[78,79]$, and can induce lethal mutagenesis of multiple viruses as well as chain termination. T-705 is a nucleobase analogue (the base of a nucleoside without ribose), a pyrazinamide derivative that resemble adenine or guanine upon rotation of its amido group [80]. In cells, T-705 nucleobase is converted enzymatically to its corresponding mononucleotide by the hypoxanthine-guanine phosphoribosyl-transferase (HGPRT) of the purine nucleotide salvage pathway [81]. Then T-705 mononucleotide is further phosphorylated to its triphosphate active form by different kinases (Figure 5) [82,83]. T-705 is interesting in that, as a nucleobase, it bypasses the first phosphorylation step that is often rate limiting for antiviral nucleosides. Instead, it is directly converted from nucleobase 
to mononucleotide by HGPRT [81]. Once converted to its nucleoside triphosphate form, T-705, like ribavirin, is incorporated by the viral RdRp as an ATP or GTP mimic to induce its antiviral effect via lethal mutagenesis [84] and/or chain termination [85,86]. Unlike ribavirin, T-705 appears to lack overt toxicity issues $[77,78]$. T-705 does not appear to inhibit host DNA or RNA polymerases $[83,86]$. Previous studies have also demonstrated that high concentrations of T-705 do not influence the synthesis of cellular RNA or DNA [82] and that T-705 does not cause mitochondrial toxicity [87]. In clinical trials, T-705 has been administered in gram amounts to patients [88,89] without significant side effects. T-705 mononucleotide is a weak inhibitor of IMPDH [82] and therefore does not affect endogenous nucleotide pools significantly.

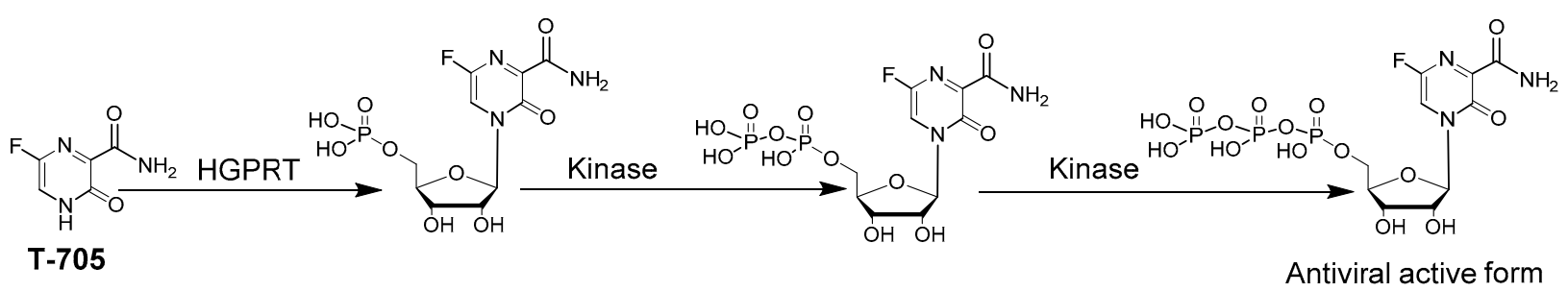

Figure 5. T-705/Favipiravir activation mechanism.

As mentioned earlier, T-705 induces viral lethal mutagenesis but T-705 can also display antiviral activity through viral RNA chain termination. These two antiviral effects, lethal mutagenesis and chain termination, appear antinomic since these mechanisms should exclude each other. However, a recent publication by Canard and colleagues seems to reconcile both mechanisms [80] by taking into consideration the ambiguous base-pairing nature of T-705. This work points to the likely different mechanism of action depending on whether T-705 triphosphate (and its analogue T-1105) are incorporated in place of ATP or GTP. Unfortunately, while the broad-spectrum antiviral activity of T-705 is remarkable in vitro and in vivo, T-705's strong antiviral effect did not translate into humans during the JIKI Trial against Ebola infections [90] and SARS-CoV-2 clinical trials where T-705 provided only moderate benefits upon early treatment at high doses [89]. One of the major limitations to the use of T-705 in humans is the lower than expected plasma concentration [91,92], including an unanticipated drop in drug concentration observed in patients enrolled in the JIKI Ebola trial [92]. This drop may occur because T-705 possesses a short half-life $(2.5-5 \mathrm{~h})$ resulting from rapid renal elimination in the hydroxylated form mediated by aldehyde oxidase [93]. In other words, a major portion of T-705 is eliminated before it gets a chance to be bioactivated to its antiviral form. The fact that T-705 demonstrates a strong antiviral activity against different viruses in a variety of animal models including mice, Guinea pigs, and non-human primates points to the likely human-specific limitations of T-705. Alternatives to T-705 [77,94] and/or strategies to increase its potency are therefore needed.

\section{Conclusions and Perspectives}

The recent and increasing number of viral outbreaks without available treatments underline the critical need to develop broad-spectrum antiviral drugs essential to treat patients rapidly and efficiently. Host-targeted and virus-targeted broad-spectrum antiviral strategies are both needed and likely complementary to offer best possible antiviral coverage and a variety of treatments. Overall, broad-spectrum antiviral drugs are more difficult to design compared to classical virus-specific drugs, due to the differences among viruses, not only in their structures, but also in their behaviors once infecting the host. Indeed, some viruses might require an organ-specific treatment due to the virus tissue tropism while other viruses might require a systemic treatment to reduce viremia. There is a discrepancy between the need of broad-spectrum drug treatments and the antiviral drug research pattern that favors virus-specific research. Antiviral drug research most often uses the logical approach, one virus, one target, one drug (broadly active or not) to clearly understand how a drug is working against a specific virus. Innovation at multiple 
levels are required to increase discovery of broad-spectrum antiviral drugs, such as the discovery of novel biological mechanisms shared by multiple viruses and the design of medicinal chemistry approaches to target these mechanisms. Additionally, even the most active broad-spectrum antiviral drugs display a range of antiviral activities depending on the virus. Therefore, studying drug combinations to limit drug resistance development and to increase antiviral efficacy is also needed.

Author Contributions: L.F.B. developed, designed, and wrote the review; R.J.G. and M.T.A. participated in the writing, edited, and revised the manuscript. All authors have read and agreed to the published version of the manuscript.

Funding: This research received no external funding.

Institutional Review Board Statement: Not applicable.

Informed Consent Statement: Not applicable.

Data Availability Statement: Not applicable.

Acknowledgments: We thank colleagues from the Center for Drug Design at the University of Minnesota for helpful feedback.

Conflicts of Interest: The authors declare no conflict of interest.

\section{References}

1. Sofia, M.J.; Bao, D.; Chang, W.; Du, J.; Nagarathnam, D.; Rachakonda, S.; Reddy, P.G.; Ross, B.S.; Wang, P.; Zhang, H.-R.; et al. Discovery of a $\beta$-D. J. Med. Chem. 2010, 53, 7202-7218. [CrossRef] [PubMed]

2. Van Norman, G.A. Drugs, Devices, and the FDA: Part 1. JACC Basic Transl. Sci. 2016, 1, 170-179. [CrossRef]

3. Cenciarelli, O.; Pietropaoli, S.; Malizia, A.; Carestia, M.; D’Amico, F.; Sassolini, A.; Di Giovanni, D.; Rea, S.; Gabbarini, V.; Tamburrini, A.; et al. Ebola Virus Disease 2013-2014 Outbreak in West Africa: An Analysis of the Epidemic Spread and Response. Int. J. Microbiol. 2015, 2015, 1-12. [CrossRef] [PubMed]

4. Mackay, I.M.; Arden, K.E. MERS coronavirus: Diagnostics, epidemiology and transmission. Virol. J. 2015, 12, 222. [CrossRef] [PubMed]

5. Drosten, C.; Günther, S.; Preiser, W.; van der Werf, S.; Brodt, H.-R.; Becker, S.; Rabenau, H.; Panning, M.; Kolesnikova, L.; Fouchier, R.A.M.; et al. Identification of a Novel Coronavirus in Patients with Severe Acute Respiratory Syndrome. N. Engl. J. Med. 2003, 348, 1967-1976. [CrossRef]

6. Contini, C.; Di Nuzzo, M.; Barp, N.; Bonazza, A.; De Giorgio, R.; Tognon, M.; Rubino, S. The novel zoonotic COVID-19 pandemic: An expected global health concern. J. Infect. Dev. Countries 2020, 14, 254-264. [CrossRef]

7. Chowell, G.; Echevarría-Zuno, S.; Viboud, C.; Simonsen, L.; Tamerius, J.; Miller, M.A.; Borja-Aburto, V.H.; Peiris, J.S.M. Characterizing the Epidemiology of the 2009 Influenza A/H1N1 Pandemic in Mexico. PLoS Med. 2011, 8, e1000436. [CrossRef]

8. Salles, T.S.; da Encarnação Sá-Guimarães, T.; de Alvarenga, E.S.L.; Guimarães-Ribeiro, V.; de Meneses, M.D.F.; de Castro-Salles, P.F.; Dos Santos, C.R.; do Amaral Melo, A.C.; Soares, M.R.; Ferreira, D.F.; et al. History, epidemiology and diagnostics of dengue in the American and Brazilian contexts: A review. Parasites Vectors 2018, 11, 264. [CrossRef]

9. Zanluca, C.; Melo, V.C.A.d.; Mosimann, A.L.P.; Santos, G.I.V.D.; Santos, C.N.D.D.; Luz, K.; Dos Santos, G.I.V.; Dos Santos, C.N.D. First report of autochthonous transmission of Zika virus in Brazil. Memórias Do Inst. Oswaldo Cruz. 2015, 110, 569-572. [CrossRef]

10. Rasmussen, S.A.; Jamieson, D.J.; Honein, M.A.; Petersen, L.R. Zika Virus and Birth Defects-Reviewing the Evidence for Causality. N. Engl. J. Med. 2016, 374, 1981-1987. [CrossRef]

11. Barrett, A.D.T. West Nile in Europe: An increasing public health problem. J. Travel Med. 2018, 25. [CrossRef] [PubMed]

12. Mayer, S.V.; Tesh, R.B.; Vasilakis, N. The emergence of arthropod-borne viral diseases: A global prospective on dengue, chikungunya and zika fevers. Acta Trop. 2017, 166, 155-163. [CrossRef]

13. Lindahl, J.F.; Grace, D. The consequences of human actions on risks for infectious diseases: A review. Infect. Ecol. Epidemiol. 2015, 5, 30048. [CrossRef] [PubMed]

14. Beyer, R.M.; Manica, A.; Mora, C. Shifts in global bat diversity suggest a possible role of climate change in the emergence of SARS-CoV-1 and SARS-CoV-2. Sci. Total Environ. 2021, 767, 145413. [CrossRef] [PubMed]

15. Pronker, E.S.; Weenen, T.C.; Commandeur, H.; Claassen, E.H.J.H.M.; Osterhaus, A.D.M.E.; Vasilakis, N. Risk in Vaccine Research and Development Quantified. PLoS ONE 2013, 8, e57755. [CrossRef] [PubMed]

16. Mercorelli, B.; Palù, G.; Loregian, A. Drug Repurposing for Viral Infectious Diseases: How Far Are We? Trends Microbiol. 2018, 26, 865-876. [CrossRef]

17. Sidwell, R.W.; Huffman, J.H.; Khare, G.P.; Allen, L.B.; Witkowski, J.T.; Robins, R.K.; Khare, L.G.P.; Allen, B.; Witkowski, R.J.T.; Robins, K. Broad-Spectrum Antiviral Activity of Virazole: 1-f8- D-Ribofuranosyl- 1,2,4-triazole- 3-carboxamide. Science 1972, 177, 705-706. [CrossRef] 
18. Witkowski, J.T.; Robins, R.K.; Sidwell, R.W.; Simon, L.N.; Robins, R.K.; Sidwell, R.W.; Simon, L.N. Design, synthesis, and broad spectrum antiviral activity of 1-.beta.-D-ribofuranosyl-1,2,4-triazole-3-carboxamide and related nucleosides. J. Med. Chem. 1972, 15, 1150-1154. [CrossRef]

19. Balzarini, J.; Keyaerts, E.; Vijgen, L.; Egberink, H.; De Clercq, E.; Van Ranst, M.; Printsevskaya, S.S.; Olsufyeva, E.N.; Solovieva, S.E.; Preobrazhenskaya, M.N. Inhibition of feline (FIPV) and human (SARS) coronavirus by semisynthetic derivatives of glycopeptide antibiotics. Antiviral Res. 2006, 72, 20-33. [CrossRef]

20. Szúcs, Z.; Naesens, L.; Stevaert, A.; Ostorházi, E.; Batta, G.; Herczegh, P.; Borbás, A. Reprogramming of the Antibacterial Drug Vancomycin Results in Potent Antiviral Agents Devoid of Antibacterial Activity. Pharmaceuticals. 2020, 13, 139. [CrossRef]

21. Ji, X.; Li, Z. Medicinal chemistry strategies toward host targeting antiviral agents. Med. Res. Rev. 2020, 40, 1519-1557. [CrossRef] [PubMed]

22. Saiz, J.-C.; Oya, N.J.d.; Blázquez, A.-B.; Escribano-Romero, E.; Martín-Acebes, M.A.; Oya, N.; Martín-Acebes, M. Host-Directed Antivirals: A Realistic Alternative to Fight Zika Virus. Viruses 2018, 10, 453. [CrossRef]

23. Schaeffer, H.J.; Gurwara, S.; Vince, R.; Bittner, S.; Schaeffer, H.J.; Vince, R. Novel substrate of adenosine deaminase. J. Med. Chem. 1971, 14, 367-369. [CrossRef] [PubMed]

24. De Clercq, E. Antiviral therapy for human immunodeficiency virus infections. Clin. Microbiol. Rev. Cmr. 1995, 8, 200-239. [CrossRef]

25. Balzarini, J. Effect of antimetabolite drugs of nucleotide metabolism on the anti-human immunodeficiency virus activity of nucleoside reverse transcriptase inhibitors. Pharmacol. Ther. 2000, 87, 175-187. [CrossRef]

26. Clercq, E.D. Antivirals and antiviral strategies. Nat. Rev. 2004, 2, 704-720. [CrossRef] [PubMed]

27. Seley-Radtke, K.L.; Yates, M.K. The evolution of nucleoside analogue antivirals: A review for chemists and non-chemists. Part 1: Early structural modifications to the nucleoside scaffold. Antiviral Res. 2018, 154, 66-86. [CrossRef]

28. Yates, M.K.; Seley-Radtke, K.L. The evolution of antiviral nucleoside analogues: A review for chemists and non-chemists. Part II: Complex modifications to the nucleoside scaffold. Antiviral Res. 2019, 162, 5-21. [CrossRef]

29. Eyer, L.; Nencka, R.; de Clercq, E.; Seley-Radtke, K.; Růžek, D. Nucleoside analogs as a rich source of antiviral agents active against arthropod-borne flaviviruses. Antivir. Chem. Chemother. 2018, 26, 204020661876129. [CrossRef]

30. Stein, D.S.; Moore, K.H.P. Phosphorylation of Nucleoside Analog Antiretrovirals: A Review for Clinicians. Pharmacother. Off. J. Am. Coll. Clin. Pharm. 2001, 21, 11-34. [CrossRef]

31. Olsen, D.B.; Eldrup, A.B.; Bartholomew, L.; Bhat, B.; Bosserman, M.R.; Ceccacci, A.; Colwell, L.F.; Fay, J.F.; Flores, O.A.; Getty, K.L.; et al. A 7-Deaza-Adenosine Analog Is a Potent and Selective Inhibitor of Hepatitis C Virus Replication with Excellent Pharmacokinetic Properties. Antimicrob. Agents Chemother. Aac. 2004, 48, 3944-3953. [CrossRef]

32. Sofia, M.J. Nucleotide Prodrugs for the Treatment of HCV Infection. Anti-Viral Agents 2013, 67, 39-73. [CrossRef]

33. Mukherji, E.; Au, J.L.; Mathes, L.E. Differential antiviral activities and intracellular metabolism of 3'-azido-3'-deoxythymidine and 2',3'-dideoxyinosine in human cells. Antimicrob. Agents Chemother. Aac. 1994, 38, 1573-1579. [CrossRef]

34. Lavie, A.; Schlichting, I.; Vetter, I.R.; Konrad, M.; Reinstein, J.; Goody, R.S.; Lavie, A.; Schlichting, I.; Vetter, I.R.; Konrads, M.; et al. The bottleneck in AZT activation. Nat. Med. 1997, 3, 922-924. [CrossRef] [PubMed]

35. Golitsina, N.L.; Danehy, F.T.; Fellows, R.; Cretton-Scott, E.; Standring, D.N. Evaluation of the role of three candidate human kinases in the conversion of the hepatitis $\mathrm{C}$ virus inhibitor 2'-C-methyl-cytidine to its $5^{\prime}$-monophosphate metabolite. Antivir. Res. 2010, 85, 470-481. [CrossRef] [PubMed]

36. McGuigan, C.; Harris, S.A.; Daluge, S.M.; Gudmundsson, K.S.; McLean, E.W.; Burnette, T.C.; Marr, H.; Hazen, R.; Condreay, L.D.; Johnson, L.; et al. Application of Phosphoramidate Pronucleotide Technology to Abacavir Leads to a Significant Enhancement of Antiviral Potency. J. Med. Chem. 2005, 48, 3504-3515. [CrossRef] [PubMed]

37. McGuigan, C.; Kelleher, M.R.; Perrone, P.; Mulready, S.; Luoni, G.; Daverio, F.; Rajyaguru, S.; Le Pogam, S.; Najera, I.; Martin, J.A.; et al. The application of phosphoramidate ProTide technology to the potent anti-HCV compound $4^{\prime}$-azidocytidine (R1479). Bioorg. Med. Chem. Lett. 2009, 19, 4250-4254. [CrossRef]

38. McGuigan, C.; Perrone, P.; Madela, K.; Neyts, J. The phosphoramidate ProTide approach greatly enhances the activity of ß-2'-C-methylguanosine against hepatitis C virus. Bioorganic Med. Chem. Lett. 2009, 19, 4316-4320. [CrossRef]

39. Brandl, M.; Wu, X.; Holper, M.; Hong, L.; Jia, Z.; Birudaraj, R.; Reddy, M.; Alfredson, T.; Tran, T.; Larrabee, S.; et al. Physicochemical Properties of the Nucleoside Prodrug R1626 Leading to High Oral Bioavailability. Drug Dev. Ind. Pharm. $2008,34,683-691$. [CrossRef]

40. Warren, T.K.; Jordan, R.; Lo, M.K.; Ray, A.S.; Mackman, R.L.; Soloveva, V.; Siegel, D.; Perron, M.; Bannister, R.; Hui, H.C.; et al. Therapeutic efficacy of the small molecule GS-5734 against Ebola virus in rhesus monkeys. Nature 2016, 531, 381-385. [CrossRef]

41. de Wit, E.; Feldmann, F.; Cronin, J.; Jordan, R.; Okumura, A.; Thomas, T.; Scott, D.; Cihlar, T.; Feldmann, H. Prophylactic and therapeutic remdesivir (GS-5734) treatment in the rhesus macaque model of MERS-CoV infection. Proc. Natl. Acad. Sci. USA 2020, 117, 6771-6776. [CrossRef]

42. Beigel, J.H.; Tomashek, K.M.; Dodd, L.E.; Mehta, A.K.; Zingman, B.S.; Kalil, A.C.; Hohmann, E.; Chu, H.Y.; Luetkemeyer, A.; Kline, S.; et al. Remdesivir for the Treatment of Covid-19_Final Report. N. Engl. J. Med. 2020, 383, 1813-1826. [CrossRef]

43. Grein, J.; Ohmagari, N.; Shin, D.; Diaz, G.; Asperges, E.; Castagna, A.; Feldt, T.; Green, G.; Green, M.L.; Lescure, F.-X.; et al. Compassionate Use of Remdesivir for Patients with Severe Covid-19. N. Engl. J. Med. 2020, 382, 2327-2336. [CrossRef] 
44. Siegel, D.; Hui, H.C.; Doerffler, E.; Clarke, M.O.; Chun, K.; Zhang, L.; Neville, S.; Carra, E.; Lew, W.; Ross, B.; et al. Discovery and Synthesis of a Phosphoramidate Prodrug of a Pyrrolo[2,1-f][triazin-4-amino] Adenine C -Nucleoside (GS-5734) for the Treatment of Ebola and Emerging Viruses. J. Med. Chem. 2017, 60, 1648-1661. [CrossRef]

45. Malin, J.J.; Suárez, I.; Priesner, V.; Fätkenheuer, G.; Rybniker, J. Remdesivir against COVID-19 and Other Viral Diseases. Clin. Microbiol. Rev. Cmr. 2020, 34. [CrossRef]

46. Kokic, G.; Hillen, H.S.; Tegunov, D.; Dienemann, C.; Seitz, F.; Schmitzova, J.; Farnung, L.; Siewert, A.; Höbartner, C.; Cramer, P. Mechanism of SARS-CoV-2 polymerase stalling by remdesivir. Nat. Commun. 2021, 12, 279. [CrossRef]

47. Tchesnokov, E.P.; Feng, J.Y.; Porter, D.P.; Götte, M.; Tchesnokov, E.; Feng, J.; Porter, D. Mechanism of Inhibition of Ebola Virus RNA-Dependent RNA Polymerase by Remdesivir. Viruses 2019, 11, 326. [CrossRef] [PubMed]

48. Gordon, C.J.; Tchesnokov, E.P.; Woolner, E.; Perry, J.K.; Feng, J.Y.; Porter, D.P.; Götte, M. Remdesivir is a direct-acting antiviral that inhibits RNA-dependent RNA polymerase from severe acute respiratory syndrome coronavirus 2 with high potency. J. Biol. Chem. 2020, 295, 6785-6797. [CrossRef]

49. Yin, W.; Mao, C.; Luan, X.; Shen, D.-D.; Shen, Q.; Su, H.; Wang, X.; Zhou, F.; Zhao, W.; Gao, M.; et al. Structural basis for inhibition of the RNA-dependent RNA polymerase from SARS-CoV-2 by remdesivir. Science 2020, 368, 1499-1504. [CrossRef] [PubMed]

50. Wang, Q.; Wu, J.; Wang, H.; Gao, Y.; Liu, Q.; Mu, A.; Ji, W.; Yan, L.; Zhu, Y.; Zhu, C.; et al. Structural Basis for RNA Replication by the SARS-CoV-2 Polymerase. Cell 2020, 182, 417-428.e413. [CrossRef] [PubMed]

51. Bouvet, M.; Imbert, I.; Subissi, L.; Gluais, L.; Canard, B.; Decroly, E.; Bouvet, M.; Imbert, I.; Subissi, L.; Gluais, L.; et al. RNA 3'-end mismatch excision by the severe acute respiratory syndrome coronavirus nonstructural protein nsp10/nsp14 exoribonuclease complex. Proc. Natl. Acad. Sci. USA 2012, 109, 9372-9377. [CrossRef]

52. McCoy, J.A.; Short, W.R.; Srinivas, S.K.; Levine, L.D.; Hirshberg, A. Compassionate use of remdesivir for treatment of severe coronavirus disease 2019 in pregnant women at a United States academic center. Am. J. Obstet. Gynecol. Mfm. 2020, 2, 100164. [CrossRef]

53. Jorgensen, S.C.J.; Kebriaei, R.; Dresser, L.D. Remdesivir: Review of Pharmacology, Pre-clinical Data, and Emerging Clinical Experience for COVID-19. Pharmacother. Off. J. Am. Coll. Clin. Pharm. 2020, 40, 659-671. [CrossRef]

54. Ferreira, V.L.; Leonart, L.P.; Tonin, F.S.; Borba, H.H.L.; Pontarolo, R. Sustained Virological Response in Special Populations with Chronic Hepatitis C Using Interferon-Free Treatments: A Systematic Review and Meta-analysis of Observational Cohort Studies. Clin. Drug Investig. 2018, 38, 389-400. [CrossRef] [PubMed]

55. Mucenic, M.; Brandão, A.B.d.M.; Marroni, C.A.; Fleck Junior, A.d.M.; Zanotelli, M.L.; Leipnitz, I.; Meine, M.H.; Kiss, G.; Martini, J.; Schlindwein, E.S.; et al. Sofosbuvir, ribavirin and pegylated interferon for a daclatasvir-resistent genotype 3 hepatitis $C$ virus: Case report and review. Rev. Do Inst. De Med. Trop. De São Paulo J. São Paulo Inst. Trop. Med. Publ. Inst. De Med. Trop. 2019, 61, e12. [CrossRef] [PubMed]

56. Ramírez-Olivencia, G.; Estébanez, M.; Membrillo, F.J.; Ybarra, M.D.C.; Ybarra, M.d.C. Uso de ribavirina en virus distintos de la hepatitis C. Una revisión de la evidencia. Enferm. Infecc. Y Microbiol. Clínica 2019, 37, 602-608. [CrossRef] [PubMed]

57. McCormick, J.B.; King, I.J.; Webb, P.A.; Scribner, C.L.; Craven, R.B.; Johnson, K.M.; Elliott, L.H.; Belmont-Williams, R.; McCormick, J.B.; King, I.J.; et al. Lassa Fever. N. Engl. J. Med. 1986, 314, 20-26. [CrossRef]

58. Willis, R.C.; Carson, D.A.; Seegmiller, J.E. Adenosine kinase initiates the major route of ribavirin activation in a cultured human cell line. Proc. Natl. Acad. Sci. USA 1978, 75, 3042-3044. [CrossRef] [PubMed]

59. Graci, J.D.; Cameron, C.E. Mechanisms of action of ribavirin against distinct viruses. Rev. Med Virol. 2006, 16, 37-48. [CrossRef] [PubMed]

60. Sintchak, M.D.; Nimmesgern, E.; Sintchak, M.D.; Nimmesgern, E. The structure of inosine $5^{\prime}$-monophosphate dehydrogenase and the design of novel inhibitors. Immunopharmacology 2000, 47, 163-184. [CrossRef]

61. Hultgren, C.; Milich, D.R.; Weiland, O.; Sällberg, M. The antiviral compound ribavirin modulates the Thelper (Th) $1 /$ Th2 subset balance in hepatitis B and C virus-specific immune responses. J. Gen. Virol. 1998, 79, 2381-2391. [CrossRef] [PubMed]

62. Prusiner, P.; Sundaralingam, M. A New Class of Synthetic Nucleoside Analogues with Broad-spectrum Antiviral Properties. Nat. New Biol. 1973, 244, 116-118. [CrossRef]

63. Kentsis, A.; Topisirovic, I.; Culjkovic, B.; Shao, L.; Borden, K.L.B.; Kentsis, A.; Topisirovic, I.; Culjkovic, B.; Shao, L.; Borden, K.L.B. Ribavirin suppresses eIF4E-mediated oncogenic transformation by physical mimicry of the 7-methyl guanosine mRNA cap. Proc. Natl. Acad. Sci. USA 2004, 101, 18105-18110. [CrossRef] [PubMed]

64. Eriksson, B.; Helgstrand, E.; Johansson, N.G.; Larsson, A.; Misiorny, A.; Norén, J.O.; Philipson, L.; Stenberg, K.; Stening, G.; Stridh, S.; et al. Inhibition of Influenza Virus Ribonucleic Acid Polymerase by Ribavirin Triphosphate. Antimicrob. Agents Chemother. Aac. 1977, 11, 946-951. [CrossRef] [PubMed]

65. Maag, D.; Castro, C.; Hong, Z.; Cameron, C.E.; Maag, D.; Castro, C.; Hong, Z.; Cameron, C.E. Hepatitis C Virus RNA-dependent RNA Polymerase (NS5B) as a Mediator of the Antiviral Activity of Ribavirin. J. Biol. Chem. 2001, 276, 46094-46098. [CrossRef] [PubMed]

66. Toltzis, P.; O'Connell, K.; Patterson, J.L. Effect of phosphorylated ribavirin on vesicular stomatitis virus transcription. Antimicrob. Agents Chemother. Aac. 1988, 32, 492-497. [CrossRef]

67. Kamar, N.; Rostaing, L.; Abravanel, F.; Garrouste, C.; Lhomme, S.; Esposito, L.; Basse, G.; Cointault, O.; Ribes, D.; Nogier, M.B.; et al. Ribavirin Therapy Inhibits Viral Replication on Patients With Chronic Hepatitis E Virus Infection. Gastroenterology. 2010, 139, 1612-1618. [CrossRef] 
68. Crotty, S.; Maag, D.; Arnold, J.J.; Zhong, W.; Lau, J.Y.; Hong, Z.; Andino, R.; Cameron, C.E. The broad-spectrum antiviral ribonucleoside ribavirin is an RNA virus mutagen. Nat. Med. 2000, 6, 1375-1379. [CrossRef]

69. Crotty, S.; Cameron, C.E.; Andino, R. RNA virus error catastrophe: Direct molecular test by using ribavirin. Proc. Natl. Acad. Sci. USA 2001, 98, 6895-6900. [CrossRef] [PubMed]

70. Cuevas, J.M.; González-Candelas, F.; Moya, A.; Sanjuán, R. Effect of Ribavirin on the Mutation Rate and Spectrum of Hepatitis C Virus In Vivo. J. Virol. 2009, 83, 5760-5764. [CrossRef]

71. Drake, J.W.; Holland, J.J. Mutation rates among RNA viruses. Proc. Natl. Acad. Sci. USA 1999, 96, 13910-13913. [CrossRef] [PubMed]

72. Sanjuan, R.; Nebot, M.R.; Chirico, N.; Mansky, L.M.; Belshaw, R. Viral mutation rates. J. Virol. 2010, 84, 9733-9748. [CrossRef] [PubMed]

73. Domingo, E.; Escarmís, C.; Sevilla, N.; Moya, A.; Elena, S.F.; Quer, J.; Novella, I.S.; Holland, J.J.; Domingo, E.; Escarmís, C.; et al. Basic concepts in RNA virus evolution. FASEB J. 1996, 10, 859-864. [CrossRef] [PubMed]

74. Steinhauer, D.A.; Domingo, E.; Holland, J.J.; Steinhauer, D.A.; Domingo, E.; Holland, J.J. Lack of evidence for proofreading mechanisms associated with an RNA virus polymerase. Gene 1992, 122, 281-288. [CrossRef]

75. Holland, J.J.; Domingo, E.; de la Torre, J.C.; Steinhauer, D.A. Mutation frequencies at defined single codon sites in vesicular stomatitis virus and poliovirus can be increased only slightly by chemical mutagenesis. J. Virol. 1990, 64, 3960-3962. [CrossRef] [PubMed]

76. Müller, W.E.; Maidhof, A.; Taschner, H.; Zahn, R.K.; Müller, W.E.G.; Maidhof, A.; Taschner, H.; Zahn, R.K. Virazole (1- $\beta-d-$ ribofuranosyl-1,2,4-triazole-3-carboxamide; A cytostatic agent. Biochem. Pharmacol. 1977, 26, 1071-1075. [CrossRef]

77. Qiu, L.; Patterson, S.E.; Bonnac, L.F.; Geraghty, R.J. Nucleobases and corresponding nucleosides display potent antiviral activities against dengue virus possibly through viral lethal mutagenesis. PLoS Negl. Trop. Dis. 2018, 12, e0006421. [CrossRef]

78. Furuta, Y.; Takahashi, K.; Fukuda, Y.; Kuno, M.; Kamiyama, T.; Kozaki, K.; Nomura, N.; Egawa, H.; Minami, S.; Watanabe, Y.; et al. In Vitro and In Vivo Activities of Anti-Influenza Virus Compound T-705. Antimicrob. Agents Chemother. Aac. 2002, 46, 977-981. [CrossRef]

79. Delang, L.; Abdelnabi, R.; Neyts, J. Favipiravir as a potential countermeasure against neglected and emerging RNA viruses. Antivir. Res. 2018, 153, 85-94. [CrossRef]

80. Shannon, A.; Selisko, B.; Le, N.-T.-T.; Huchting, J.; Touret, F.; Piorkowski, G.; Fattorini, V.; Ferron, F.; Decroly, E.; Meier, C.; et al. Rapid incorporation of Favipiravir by the fast and permissive viral RNA polymerase complex results in SARS-CoV-2 lethal mutagenesis. Nat. Commun. 2020, 11, 4682. [CrossRef] [PubMed]

81. Naesens, L.; Guddat, L.W.; Keough, D.T.; van Kuilenburg, A.B.; Meijer, J.; Vande Voorde, J.; Balzarini, J. Role of human hypoxanthine guanine phosphoribosyltransferase in activation of the antiviral agent T-705 (favipiravir). Mol. Pharm. 2013, 84, 615-629. [CrossRef]

82. Furuta, Y.; Takahashi, K.; Kuno-Maekawa, M.; Sangawa, H.; Uehara, S.; Kozaki, K.; Nomura, N.; Egawa, H.; Shiraki, K. Mechanism of action of T-705 against influenza virus. Antimicrob. Agents Chemother. 2005, 49, 981-986. [CrossRef] [PubMed]

83. Furuta, Y.; Gowen, B.B.; Takahashi, K.; Shiraki, K.; Smee, D.F.; Barnard, D.L. Favipiravir (T-705), a novel viral RNA polymerase inhibitor. Antivir. Res. 2013, 100, 446-454. [CrossRef] [PubMed]

84. Baranovich, T.; Wong, S.S.; Armstrong, J.; Marjuki, H.; Webby, R.J.; Webster, R.G.; Govorkova, E.A. T-705 (favipiravir) induces lethal mutagenesis in influenza A H1N1 viruses in vitro. J. Virol. 2013, 87, 3741-3751. [CrossRef] [PubMed]

85. Jin, Z.; Smith, L.K.; Rajwanshi, V.K.; Kim, B.; Deval, J. The ambiguous base-pairing and high substrate efficiency of T-705 (Favipiravir) Ribofuranosyl 5'-triphosphate towards influenza A virus polymerase. PLoS ONE 2013, 8, e68347. [CrossRef]

86. Sangawa, H.; Komeno, T.; Nishikawa, H.; Yoshida, A.; Takahashi, K.; Nomura, N.; Furuta, Y. Mechanism of Action of T-705 Ribosyl Triphosphate against Influenza Virus RNA Polymerase. Antimicrob. Agents Chemother. Aac. 2013, 57, 5202-5208. [CrossRef]

87. Jin, Z.; Kinkade, A.; Behera, I.; Chaudhuri, S.; Tucker, K.; Dyatkina, N.; Rajwanshi, V.K.; Wang, G.; Jekle, A.; Smith, D.B.; et al. Structure-activity relationship analysis of mitochondrial toxicity caused by antiviral ribonucleoside analogs. Antivir. Res. 2017, 143, 151-161. [CrossRef]

88. Jacobs, M.; Aarons, E.; Bhagani, S.; Buchanan, R.; Cropley, I.; Hopkins, S.; Lester, R.; Martin, D.; Marshall, N.; Mepham, S.; et al. Post-exposure prophylaxis against Ebola virus disease with experimental antiviral agents: A case-series of health-care workers. Lancet Infect. Dis. 2015, 15, 1300-1304. [CrossRef]

89. Cai, Q.; Yang, M.; Liu, D.; Chen, J.; Shu, D.; Xia, J.; Liao, X.; Gu, Y.; Cai, Q.; Yang, Y.; et al. Experimental Treatment with Favipiravir for COVID-19: An Open-Label Control Study. Engineering 2020, 6, 1192-1198. [CrossRef]

90. Sissoko, D.; Laouenan, C.; Folkesson, E.; M’Lebing, A.B.; Beavogui, A.H.; Baize, S.; Camara, A.M.; Maes, P.; Shepherd, S.; Danel, C.; et al. Experimental Treatment with Favipiravir for Ebola Virus Disease (the JIKI Trial): A Historically Controlled, Single-Arm Proof-of-Concept Trial in Guinea. PLoS Med. 2016, 13, e1001967. [CrossRef] [PubMed]

91. Mentré, F.; Taburet, A.-M.; Guedj, J.; Anglaret, X.; Keïta, S.; de Lamballerie, X.; Malvy, D. Dose regimen of favipiravir for Ebola virus disease. Lancet. Infect. Dis. 2015, 15, 150-151. [CrossRef]

92. Nguyen, T.H.; Guedj, J.; Anglaret, X.; Laouenan, C.; Madelain, V.; Taburet, A.M.; Baize, S.; Sissoko, D.; Pastorino, B.; Rodallec, A.; et al. Favipiravir pharmacokinetics in Ebola-Infected patients of the JIKI trial reveals concentrations lower than targeted. PLoS Negl. Trop. Dis. 2017, 11, e0005389. [CrossRef] [PubMed] 
93. Agrawal, U.; Raju, R.; Udwadia, Z.F. Favipiravir: A new and emerging antiviral option in COVID-19. Med. J. Armed Forces. India 2020, 76, 370-376. [CrossRef] [PubMed]

94. Bonnac, L.F.; Mansky, L.M.; Patterson, S.E. Structure-activity relationships and design of viral mutagens and application to lethal mutagenesis. J. Med. Chem. 2013, 56, 9403-9414. [CrossRef] [PubMed] 